\title{
GEUS - the new national geological survey
}

\author{
Martin Ghisler
}

Director

The Geological Survey of Greenland (GGU) was amalgamated with its larger brother - the Geological Survey of Denmark (DGU) - on 1st June 1995. The merger was approved by a unanimous decision of the Danish Parliament and accepted by the Greenland Home Rule Government. The new Survey, under the Ministry for Environment and Energy, comprises a staff of 360 persons, of which 100 come from the former GGU and 20 from the Danish Lithosphere Centre (DLC), a research centre formerly administratively linked to GGU and now linked to the new Survey.

The official name of the new Survey is 'Danmarks og Grønlands Geologiske Undersøgelse', in English 'Geological Survey of Denmark and Greenland', a long and somewhat cumbersome title in both languages which, for convenience, is abbreviated for many purposes to GEUS, derived from the Danish name for a geological survey (GEologisk UnderSøgelse). The tasks of the former GGU continue unaffected by the merger, and there have been no extraordinary reductions in funding or in staff numbers. During 1996 the majority of 'GGU' staff will move from their present building at the University of Copenhagen to the premises occupied by the former DGU $5 \mathrm{~km}$ away in NW Copenhagen.

A reorganisation of the Survey is effective from the 1 May 1996. The former GGU Department of Geological Mapping (including hard rock geochemistry and age dating) and the Department of Mineral Resources (now Economic Geology) continue virtually unchanged, whereas the 'GGU' glaciologists have become part of the new Department for Hydrology and Glaciology. The most significant changes in organisation are in the field of petroleum geology, where there was an overlap between the respective departments of the former GGU and DGU; in the new Survey there is no special petroleum geological department for Greenland. The petroleum division of the new Survey responsible for the geological activities relevant for hydrocarbon exploration and exploitation within the Kingdom of Denmark (Denmark, Greenland and the Faeroe Islands) comprises three departments: the Department for Stratigraphy, the Department for Geophysics and the Department for Reservoir Geology; analytical support is provided by the laboratories of the Geochemical Department. The Survey's administration and service functions have been fully inte- grated. The leadership of the Survey comprises a Managing Director, a Director and a Vice-Director.

The new Survey's premises in NW Copenhagen, situated in the office complex occupied by the former DGU, may only be temporary ( $3-4$ years). A proposal to create a major GEOCENTRE in Copenhagen has been supported by the Ministry of Education, the Ministry of Research and Information Technology, the Ministry of Environment and Energy and the Prime Minister's Office. The proposed GEOCENTRE would comprise GEUS including DLC, together with the Geological Institute, Geological Museum and Geographical Institute of the University of Copenhagen, with the most likely site the $50000 \mathrm{~m}^{2} \emptyset_{\text {ster Vold- }}$ gade 10 complex already housing several of the involved institutes (as well as formerly GGU). Total expenses connected with renovation of the Øster Voldgade complex for the GEOCENTRE and relocation costs are estimated at 190 million Danish kroner. The final political decision on the establishment of a GEOCENTRE is ultimately linked to the overall National Research Strategy, and is expected to be taken before the end of 1996 .

\section{Advisory tasks}

GEUS has continued its advisory tasks for the Mineral Resources Administration for Greenland with respect to regulation of exploration and - hopefully - exploitation activities. In addition GEUS collaborates in geoscientific tasks with the Minerals Office of the Greenland Home Rule Government in Nuuk, Greenland, where two senior geologists with experience in the fields of mineral exploration and petroleum geology are temporarily stationed.

On behalf of the Mineral Resources Administration for Greenland (MRA) GEUS carried out inspection visits to company drilling activities in the summer and autumn of 1995: grønArctic Energy Inc. on Nuussuaq, Platinova A/S at Citronen Fjord (Peary Land), Nunaoil A/S at Stor $\varnothing$ (Nuuk) and Kirkespirdalen (Nanortalik), and RTZ at Isua (Nuuk). In addition GEUS has carried out investigation and evaluation of the geological aspects of mineral resource developments in Greenland for the MRA with special emphasis on the petroleum geological aspects onshore and offshore West Greenland. 

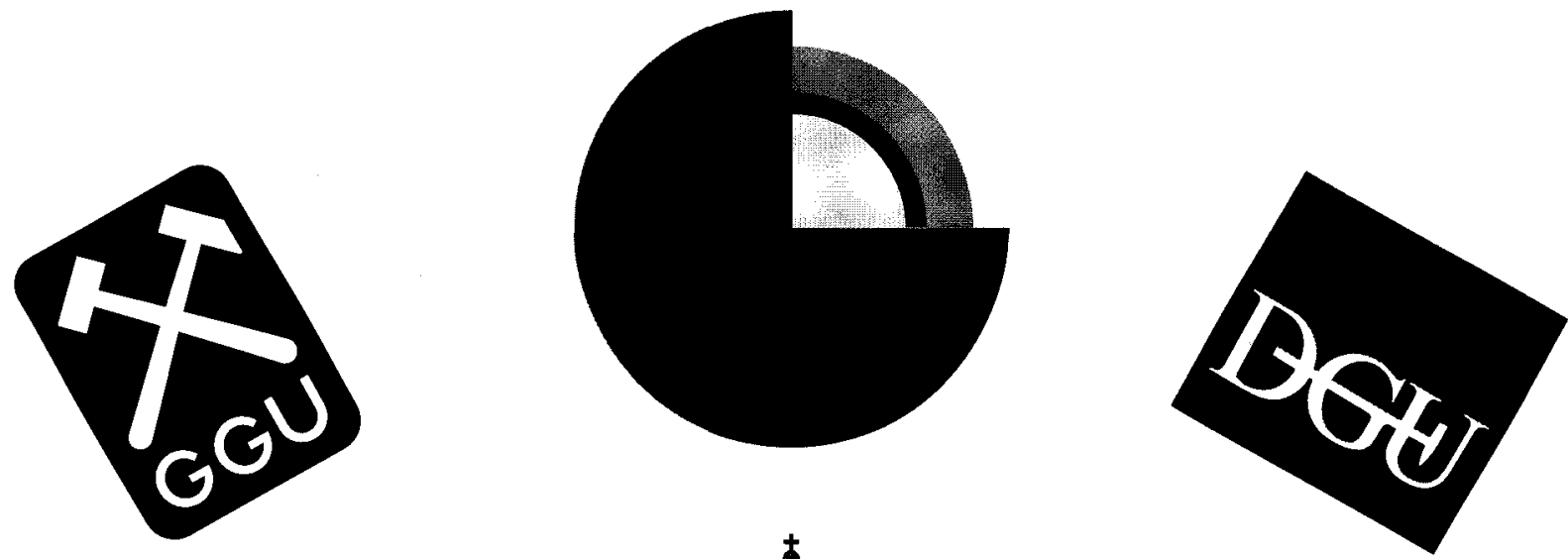

\section{Publications and promotion of Greenland mineral and hydrocarbon potential}

GEUS and the Mineral Resources Administration for Greenland continued their joint information services directed at the international oil and mining industry, in collaboration with the Minerals Office in Nuuk. This service includes presentation of geological results and information relevant to resource prospecting at meetings, symposia and exhibitions, as well as production of the newsletters Ghexis (oil and gas) and Minex (minerals). Efforts to make geological data, in the form of reports or digital data, readily accessible to companies have continued. Scientific results related to Greenland will be published by GEUS in the renamed 'Geology of Greenland, Survey Bulletin' series (a continuation of the former GGU Bulletin series and incorporating the former GGU Rapport series); this will include an annual overview of Greenland activities. Preliminary results and data formerly published in the GGU Open File Series will in the future appear as 'Reports' published by GEUS; these present data from Denmark, the Faeroe Islands and Greenland. Maps from Greenland will similarly be included in a single geodata map series comprising all types of maps of the Kingdom of Denmark.

\section{Activities and funding}

Geological, geochemical, geophysical and glaciological projects were carried out throughout Greenland in 1995. A total of 81 scientific and technical staff, including a number of guest scientists from institutions in Denmark and abroad, participated in GEUS expeditions. In addition the field activities of the Danish Lithosphere Centre comprised 65 participants (see separate review elsewhere in this volume). This volume presents an overview of the Survey's activities in Greenland during the past year. A short summary of the main field activities in 1995 is given below.

Funds for GEUS' Greenland activities in 1995 amounted to nearly 70 million DKK. Of this, 29 million Danish kroner came from external sources, the main contributor being the Danish National Research Foundation with approximately $50 \%$ for funding the activities of the Danish Lithosphere Centre.

\section{Petroleum geology}

The main activities in the petroleum geology field took place both onshore and offshore central West Greenland. On Svartenhuk Halvø a stratigraphic well was drilled to a depth of $1200 \mathrm{~m}$ in order to test the possibility for a marine source rock of mid-Cretaceous age. The well was drilled for GEUS by grønArctic Energy Inc. and funded by a special grant from the Greenland Home Rule Government and the Danish State.

Offshore GEUS carried out a reconnaissance seismic survey in the fjords and bays around Nuussuaq and acquired supplementary data on the shelf to the west of Disko. The latter was carried out with a $4.5 \mathrm{~km}$ streamer to test whether this could provide more information on the sediments underlying the basalts in this area. In addition seismic data were collected from an area west of Sisimiut, where the Kangâmiut-1 well encountered traces of hydro- 
carbons in 1976. A total of $3700 \mathrm{~km}$ of new seismic data was acquired in collaboration with Nunaoil $\mathrm{A} / \mathrm{S}$ using the Danish Navy vessel Thetis, with special funding by the Greenland Home Rule Government and the Danish State.

Geological studies focusing on aspects of petroleum generating processes were initiated in North Greenland and central East Greenland as part of a three year programme supported by the Danish Natural Science Research Council. Petroleum geological investigations in the Wandel Sea Basin in eastern North Greenland with a view to evaluating the oil potential of areas offshore the northernmost segment of the East Greenland shelf were completed.

In the area of Kangerlussuaq in southern East Greenland outcrops of Cretaceous sediments were studied in cooperation with DLC and partly funded by Danish Oil and Gas Production A/S (DOPAS).

\section{Geological mapping}

The systematic 1:500 000 geological mapping programme in eastern North Greenland was completed after three field seasons working out of a base camp at Centrum Sø. Most activity was concentrated in the region $78^{\circ}-81^{\circ} \mathrm{N}$ (map sheet no. 9), but activities supported spanned from Danmarkshavn in the south to Peary Land in the north. The project included structural, stratigraphic, and sedimentological studies within the Caledonian fold belt as well as in the foreland areas to the west. Some aspects of the field work were supported by the Carlsberg Foundation and the U.S. National Science Foundation.

In West Greenland studies of the Proterozoic Nagssugtoqidian fold belt were carried out by a DLC/GEUS group between Sisimiut and Disko Bugt. In East Greenland GEUS participated in the DLC-organised activities with studies of the basalt stratigraphy along Blosseville Kyst. GEUS joined the Ocean Drilling Programme offshore South-East Greenland (ODP Leg 163) with two scientists, one as co-chief scientist (from DLC).

\section{Mineral resource investigations}

The five-year airborne geophysical project (AEM 1994-98) financed by the Greenland Home Rule Government was continued. The survey area in 1995 covered Archaean terrain between Nuuk and Maniitsoq, from which 20000 line $\mathrm{km}$ of magnetic and electromagnetic high quality data were collected and processed. Data are available to the mining industry at low cost (with a small handling fee) in order to encourage new prospecting activities.

An aeromagnetic survey financed by the Greenland Home Rule Government and the Danish State was flown in South Greenland; 70000 line $\mathrm{km}$ of data were acquired over the ice-free areas of both the west and the east coasts of southern Greenland, including systematic coverage across the Inland Ice. On the west coast coverage reaches as far north as Ivituut. These data are also available at a modest charge.

In Inglefield Land in North-West Greenland follow-up ground work was carried out in continuation of the 1994 AEM geophysical survey. The investigations, funded by the Greenland Home Rule Government, comprised geological reconnaissance and geochemical sampling of stream sediments.

Ore geological investigations in eastern North Greenland, and especially around the Citronen Fjord zinc deposit, were initiated as part of a project focusing on ore forming processes in sedimentary basins, and including lead isotope studies. The project is supported by the Danish Natural Science Research Council.

\section{Glaciology}

Glaciological investigations in the field of climatic research have been continued by GEUS in close co-operation with the Alfred-Wegener-Institute, Bremerhaven, Germany, and the Niels Bohr Institute at the University of Copenhagen, and with the participation of scientists from several countries. The investigations, which included drilling of a small ice cap, were funded by the European Union, the Nordic Council of Ministers, the Danish Natural Science Research Council and the Danish Polar Center.

Three areas were investigated: Hans Tausen Iskappe in Peary Land, the ice margin in southern Kronprins Christian Land and the glacier Storstrømmen west of Danmarkshavn.

\section{Publications}

In 1995 a new Geological Map of Greenland at a scale of 1:2 500000 was published, which included for the first time the geology of offshore areas. A geological map of part of the Disko Bugt area in West Greenland at 1:100 000 (Ataa 69 V.3N) was also printed. A new volume in the GGU Thematic Map Series containing a set of 63 thematic maps at 1:1000 000 (mainly compilations of geochemical data) was released covering the area between Paamiut and Buksefjorden. One volume in GGU's Rapport Series (22 articles) and fourteen numbers in GGU's Open File Series were also issued. As a consequence of research activities in Greenland 24 articles were published in international scientific journals. A complete list of 1995 publications is given at the end of this volume. 